\title{
Gender Wise Saudi Investors' Awareness of Corporate Governance Mechanism and Its Importance in Their Investment Decision Making - An Empirical Study
}

\author{
Rima Al-Sager ${ }^{1}$, Durga Prasad Samontaray ${ }^{2}$ \\ ${ }^{1}$ Lecturer, Department of Finance, College of Business Administration, King Saud University, Riyadh, Kingdom \\ of Saudi Arabia \\ ${ }^{2}$ Associate Professor, Department of Finance, College of Business Administration, King Saud University, Riyadh, \\ Kingdom of Saudi Arabia \\ Correspondence: Durga Prasad Samontaray, Associate Professor, Department of Finance, College of Business \\ Administration, King Saud University, Riyadh, Kingdom of Saudi Arabia.
}

Received: January 15, 2018

Accepted: February 6, 2018

Online Published: February 12, 2018

doi:10.5539/ibr.v11n3p118

URL: https://doi.org/10.5539/ibr.v11n3p118

\begin{abstract}
This paper discusses the gender wise investors' awareness of corporate governance concepts and its importance in their investment decision process. It also answers the two questions "do investors depend on information related to corporate governance to make their investment decisions?" and "are the mechanisms of corporate governance important to them?" Books, studies, and research articles are used to enrich this paper. A survey is used as a tool to investigate the opinion of male and female investors, about corporate governance concepts and its importance on investors' decision making process. The survey shows that investors do not have a clear definition of corporate governance but they believe that it is important from companies' point of view. Also, most of investors do not always depend on information or factors that related to corporate governance as a base for their investment decisions. Mainly, Saudi investors care about board committees, disclosure and transparency as mechanisms of corporate governance.
\end{abstract}

Keywords: audit committee, board committees, board composition, board of directors, board size, CMA, compensation committee, disclosure, executive committee, nominating committee, ownership structure, Tadawul, transparency

\section{Introduction}

The downfall of worldwide corporate giants such as Enron, Xerox, Worldcom and Parmalat (to name a few, Wikipedia) has left deep scars on the corporate world in general. It has been shown that most corporate failures including Enron and Worldcom, can be caused by the lack of good corporate governance (Wymeersch, E. 2006). The US accounting scandals hastened the understanding of the wide-ranging effect poor corporate governance can have on a country's economy, through the effects on the capital markets. Such incidents have adversely affected public confidence in the reliability of corporate reporting. In Saudi Arabia, the scandals in the USA, as well as the 2006 capital market crises, have been considered as a wake-up call to the need for better corporate governance and transparency among Saudi companies.

The Corporate Governance Regulations were issued in December 2006 by the Capital Market Authority (CMA), pursuant to Resolution No. 1/212/2006 (CMA, 2006). Around 4 million Saudi investors trade in the Saudi capital market. Transparency and disclosure in the corporate world will prevent many of the risks to happen to the investors in the capital market. The best solution for that is the commitment of companies to implement the corporate governance practice as a whole. Moreover, investors' awareness of the effects and importance of corporate governance should be raised.

In Saudi Arabia, it is interesting to know the awareness of corporate governance concept and its importance among Saudi investor genders - male and female - for many reasons. First, corporate governance is not the only factor that should affect the investors' decision, but it is one of the most important influences to ensure that the companies are in the right track. Second, males form almost $86 \%$ and women are $14 \%$ out of all Saudi employees in Saudi Arabia (General Authority for Statistic: stats.gov.sa). Only 0.5\% of employees in the private 
sector (including banks and investment institutions) are women. Moreover, 20\% of the Saudi funds are being invested by women. According to this low percentage of women involved in the labor market and in wealth investment compared to men, it is interesting to measure and compare the male and women understanding of the important concept "corporate governance" and to know if there is a vivid difference between men and women in using corporate governance mechanisms to build their investment decisions. In Saudi Arabia, men follow the Islamic principles by being the responsible to work and pay for their wives and daughters. The difference between men and women roles in the Saudi society could have a big impact on their investment decisions.

In this paper, different definitions of corporate governance are provided. Important mechanisms of corporate governance, like ownership structure, board of directors, disclosure, and transparency are explained. Then, Saudi investors' awareness of corporate governance is measured. They are asked about appropriate and inappropriate definitions to examine their understanding of corporate governance concepts. Then, the effect and the importance of information, related to corporate governance, on investors' decisions are measured. Finally, results, discussion, recommendations, conclusion, and future research are presented.

\section{Literature Review}

Definition: The most popular definition of corporate governance is:"the system by which organizations are directed and controlled." Cadbury, A. (1992). Corporate governance is defined as "the exercise of power over corporate entities" (Tricker 2000, p. 403). Corporate governance is one key element in improving economic efficiency and growth as well as enhancing investor confidence. Corporate governance involves a set of relationships between a company's management, its board, its shareholders and other stakeholders. Corporate governance also provides the structure through which the objectives of the company are set, and the means of attaining those objectives and monitoring performance are determined. Good corporate governance should provide proper incentives for the board and management to pursue objectives that are in the interests of the company and its shareholders and should facilitate effective monitoring (OECD 2004, p. 11).

\section{Ownership Structure:}

Studies on corporate governance have identified two basic corporate ownership structures: concentrated and dispersed (Prempeh and Eugene, 2015). In most developed economies, the ownership structure is highly dispersed. However, in developing countries where there is a weak legal system to protect the interests of the investors, the ownership structure is highly concentrated. According to La Porta et al. (Fama, \& Jensen, 1983; La Porta and Vishny, 1997; La Porta et al., 1998; La Porta and Lopez, 1999), ownership concentration is a response to differing degrees of legal protection of minority shareholders across countries. A highly concentrated ownership structure tends to create more pressure on management to engage in activities that maximize investors and other stakeholders' interests (Che Haat, M. H. Abdul Rahman, R. and Mahenthiran, S. 2008).

Ownership structure was extended to incorporate Joint Stock type of organization where people from different sections of the society came up to provide necessary fund (Khan et al, 2004:131). In such widely-held corporation, the risk bearing function of ownership and the managerial function of control were separate functions performed by different parties. The different parties involved in the organization are having their own interests which maybe even of conflicting nature (Bhuiyan and Biswas, 2006).

La Porta et al. (2000) defines corporate governance as a set of mechanisms through which outside investors protect themselves against expropriation by corporate insiders. The degree of expropriation by insiders depends on the investment opportunities available and the cost of expropriation to the firm. Johnson et al. (2000) and Durnev and Kim (2003) suggest that insiders expropriate more when the market is bad, and take less when the market is good. These authors argue that one could address the agency problem between outsiders and corporate insiders by imposing a higher cost on expropriation by using growth opportunities, external financing and concentrated ownership. In short, high insider ownership is normally associated with management entrenchment and expropriation of firm resources.

\section{Board of Directors:}

Although Blair (1995) espouses a broad definition of corporate governance, she also recognizes its narrow application to the "structure and functioning of boards of directors" (p. 3). In fact, Blair (1995) cites the board of directors as the "single most important corporate governance mechanism" (p. 77). Similarly, Fombrun (2006) states, "The primary corporate governance mechanism is the board of directors" (p. 267). Ahmed et al. (2017) studied recently the impact of gender diverse boards on the capital market efficiency in Australia, and found that female directors on the board improve the frequency and volume of all types of continuous disclosure. Conyon $\& \mathrm{He}$ (2017) studied the relationship between board room diversity and the firm performance, of 3000 American 
firms for the year 2007-2014 and found that the presence of women on the board has a positive impact on the firm performance. Sila, Gonzalez, \& Hagendorff.(2016) investigated the board room diversity and firm risk and no evidence that female boardroom representation influences equity risk. This mixed result encouraged the current study.

\section{Board Size:}

For decades, boards of for-profit corporations were large and consisted of as many as 20 or more directors (Branson, 2007, Heidrick \& Struggles' Corporate governance report, 2009). According to "The Changing Board, cited by Pearce and Zahra (1992)", boards ranged in size from 6.2 to 14.62 members from the years 1979 through 1986. Using 1983 data, Kesner (1988) found boards at Fortune 500 companies to average about 13 members. Based on 1999 data, Carter et al. (2003) state the average board is comprised of 11 members. Among Fortune 1000 boards, Davis \& Useem (2001) cite the size as ranging from 4 to 35 directors, with an average of 11 members. Rose (2006) cites Monks and Minow's 2001 work with an average size of 12 . More recently, the average size of boards in the 2006 - 2007 report was 10.4 members (Heidrick \& Struggles, 2006 - 2007).

Jensen (1993) states that "Keeping boards small can help improve their performance. When boards get beyond seven or eight people they are less likely to function effectively and are easier for the CEO to control." (p. 865) Lipton and Lorsch (1992) also call for the adoption of small boards, and recommend that board size be limited to seven or eight members. Lipton and Lorsch (1992) and Jensen (1993) have criticized the performance of large boards, arguing that problems of poor communication, coordination of tasks, and decision making undermine the effectiveness of such groups.

\section{Board Composition:}

The composition of boards involves board independence, often expressed in terms the ratio of inside and outside directors. In fact, this aspect of composition is most commonly studied (Carter, 2003). Scholars often theorize that greater outside representation on boards of directors provides greater benefits to shareholders (Carter et al., 2003; Daily \& Dalton, 1993). Du Plessis, McConvill, \& Bagaric (2005) offer a multitude of studies that empirically do not support this position, many based on studies by Bhagat and Black (1999, 2002). In fact, Bhagat and Black (1999) cite companies such as American Express, Chrysler, General Motors, IBM, Kodak, Sears, and Westinghouse as dismal performers with outsider dominated boards. Despite the contradictory empirical evidence, Blair (1995) notes adding more outside directors to the board has been a prominent goal since the 1970s in response to scandal and litigation.

Scholarly discourse exists both in favor (Beasley, Carcello, Hermanson, \& Lapides 2000; Davidson et al., 2004) and against boards with a high representation of outside board members (Daily \& Dalton, 1993 cited Kesner, 1986; Pfeffer, 1972; Schellendger, Wood, and Tashakori, 1989). Numerous empirical investigations document situations where outsiders offer better protections for shareholder interests. Ahmed \& Ali (2017), examined 944 Australian firms and found that boardroom gender diversity is significantly and positively associated with stock liquidity.

\section{Board Committees:}

In the early 1970s, one or two standing committees were standard; but a decade later, boards at Fortune 1,000 companies had an average of 4.3 committees (Kesner, Victor \& Lamont, 1986). Today various committees existing on boards include executive, compensation, audit, nominating, public affairs, strategic planning, finance, social responsibility, investment, corporate ethics, environmental, technology, and corporate governance committees (Bilimoria \& Piderit, 1994; Blair, 1995; Davidson, Pilger, Szakmary, 2004).

While companies are free to have as many committees as they deem necessary, the three main committees are the audit, nominating, and compensation committees (Branson, 2007, Kesner et al., 1986; Lorsch \& MacIver, 1989).

\section{Executive committee:}

This committee is powerful because it can exercise the power of the full board between meetings on many issues (Branson, 2007). Bilimoria \& Piderit (1994) blend the topics of gender composition and committee membership by observing that females are relegated to certain types of committees while males more often serve on the more strategic and powerful committees.

\section{Audit committee:}

Having an audit committee comprised 100\% of independent directors was once recommended as a best practice. Independence, as defined by the Law, is an individual who is not an employee of the company and does not 
receive any remuneration from the company other than director compensation.

The purpose of the audit committee is to ensure the independence and performance of the external auditors, oversee the work of the internal auditors, and review the financial statements. Audit committees are considered to have important, positive benefits for companies (Lutzy, 2003). It is also found that companies in the volatile industries experiencing instances of financial statement fraud had fewer audit committees, less independent audit committees, or fewer audit committee meetings (Beasley et al., 2000).

\section{Nominating committee:}

Sometimes referred to as the governance committee, the nominating committee deals with ensuring boards were independent by managing the recruitment process (Branson, 2007). This means the committee is involved with identifying qualified candidates to nominate to the board.

\section{Compensation committee:}

The compensation committee primarily concerns itself with the compensation package of the executive officers (Branson, 2007), directors, and employees. This committee must be independent.

\section{Hypothesis:}

\section{Gender wise awareness of Corporate Governance Concepts:}

1. There is an agreement between male and female investors regarding the statement "Means the government owns through its funds at least $5 \%$ of the shares of listed companies" as concept of corporate governance.

2. There is an agreement between male and female investors regarding the statement "Means a set of regulations and structures which govern the relationship between shareholders and management" as concept of corporate governance.

3. There is an agreement between male and female investors regarding the statement "Means appointment of members by the government to represent it in the management of insolvent companies" as concept of corporate governance.

4. There is an agreement between male and female investors regarding the statement "Means the system by which companies are controlled and managed" as concept of corporate governance.

5. There is an agreement between male and female investors regarding the statement "Clarifies and codifies the powers of managers and owners in the company" as concept of corporate governance.

6. There is an agreement between male and female investors regarding the statement "Is not important or necessary in the company" as concept of corporate governance.

\section{Gender wise Importance of Corporate Governance Mechanisms:}

1. There is an agreement between male and female investors regarding the statement "Number of members of the board of directors" as important mechanism of corporate governance.

2. There is an agreement between male and female investors regarding the statement "Existence of independent and non-executive members (in addition to the executive members) in the Board of directors" as important mechanism of corporate governance.

3. There is an agreement between male and female investors regarding the statement "The ownership of government/sovereign funds in the company" as important mechanism of corporate governance.

4. There is an agreement between male and female investors regarding the statement "Disclosure of board members' compensations" as important mechanism of corporate governance.

5. There is an agreement between male and female investors regarding the statement "The existence of nomination and compensation committee in the company" as important mechanism of corporate governance.

6. There is an agreement between male and female investors regarding the statement "Transparency of the company in general" as important mechanism of corporate governance.

\section{Data and Methodology}

Sampling Methodology:

The population contains all Saudi investors who are trading in the Saudi Arabian capital market (i.e. Tadawul). The size of population is unknown as there is no formal source for the number of Saudi investors in Saudi capital market. However, it is estimated by researchers that this number may be approximately four million investors.

The survey has been circulated among investors in different local locations in the Kingdom of Saudi Arabia and was addressed to Saudi investors only, and therefore all responses came from the right target sample. Due to the 
nature of this research, convenience sample is used.

Thompson (1992) pointed out to determine the appropriate sample size when there is need to conduct a field study exploring the views of a sample of the target so that this sample reflect the similarities and differences of the views of the original population of the study. According to that, the sample size is

Sample Size $=$

$$
\begin{gathered}
\frac{N p(1-p)}{(N-1) \frac{c * c}{Z * Z}+p(1-p)} \\
\frac{4,000,000 *(0.5) *(0.5)}{(4,000,000-1) * \frac{0.06 * 0.06}{1,96 * 1,96}+(0.5) *(0.5)}
\end{gathered}
$$

$=267$

Where:

$\mathrm{Z}$ is the value under the normal distribution curve with $95 \%$ confidence interval

$\mathrm{P}$ is the percent of selecting the correct answer which is equal 0.5 because the selection of respondents is not unknown \&

$\mathrm{C}$ is the confidence level represented in $+6 \%$ or $-6 \%$ percent

Survey Design:

The survey was prepared in accordance with the corporate governance principles and based on the regulations issued by the Saudi Capital Market Authority (CMA). Another source for preparing the survey was a survey about "The Opinions of Investors about the Reality of the Continuing Disclosure of Listed Companies in the Saudi Capital Market". This survey was designed and distributed by the Saudi Capital Market Authority.

The survey is divided into 4 parts:

First: The primary data: the first question in this part is about the nationality to be sure just the Saudi investors are the respondents. The second question is about the gender.

Second: in this part there are six statements to measure the awareness of investors about corporate governance. Three statements are appropriate definitions and the rest are inappropriate.

Third: The statements in this part measure the extent to which investor depends on information that related to corporate governance and its importance when making investment decision.

Fourth: In this part, seven statements are written to measure the Importance of the mechanisms of corporate governance for the investor

To improve the survey, it was distributed to a small sample, in the first phase. Some modifications have been made, then, after receiving feedback from the sample. These modifications have included eliminating some personal and some corporate governance-related questions.

\section{Data Collection:}

The survey has been circulated to different areas where Saudi investors can be located. One of the most important areas is local trading rooms where majority of the Saudi investors spend considerable time in trading local shares, and therefore it is a strategic place to circulate the survey.

In addition, the customers and employees of banks in different branches were part of the target sample. Large proportions of them are trading in the Saudi capital market. The survey has been circulated also among private-sector companies who provide financial and investment services to Saudi investors.

The survey was also circulated in other locations such as universities, schools, and hospitals to target different sectors and backgrounds of investors in the local market.

Data Analysis:

In this research, two types of statistical analysis are applied. The first is descriptive statistics, frequency and its percents of survey responses. This type of analysis is used to measure the awareness among different samples. It also shows the percentage of investors who care about corporate governance mechanisms, and build their investment decisions based on it. 
The second type of statistical analysis is analytical statistics which are applied to test the hypothesis. It tests the effect of the investors' characteristics on their awareness, corporate governance-based investment decisions, and the importance of corporate governance mechanisms for them. Both types of statistical analysis will be applied using SPSS.

\section{Descriptive Results Analysis}

\subsection{Awareness of Investors about Corporate Governance Concepts}

To measure the investors' awareness of corporate governance concepts, 6 concepts where addressed in which 3 are appropriate and 3 are inappropriate.

The appropriate concepts are:

1. Means a set of regulations and structures which govern the relationship between shareholders and management

2. Means the system by which companies are controlled and managed

3. Clarifies and codifies the powers of managers and owners in the company

The inappropriate concepts are:

1. Means the government owns through its funds at least $5 \%$ of the shares of listed companies

2. Means appointment of members by the government to represent it in the management of insolvent companies

3. Is not important or necessary in the company

Table 4.1.1 presents the frequencies and percentages of investors' respondents to the concepts of the corporate governance. For the appropriate concepts, the results can be concluded as follows:

> From a total of 270 respondents, $41.1 \%$ on investors agree that "Means a set of regulations and structures which govern the relationship between shareholders and management" is a concept of corporate governance.

$>$ With regard to the statement "corporate governance means the system by which companies are controlled and managed", it is found that $63 \%$ of the respondents agree of its meaning as corporate governance concept.

$>65.9 \%$ of the sample agree and believe that the corporate governance "Clarifies and codifies the powers of managers and owners in the company".

For the inappropriate concepts, the results can be summarized as follows:

$>68.9 \%$ of respondents agree with the first inappropriate definition which describes corporate definition as "Means the government owns through its funds at least $5 \%$ of the shares of listed companies".

$>$ Although "means appointment of members by the government to represent it in the management of insolvent companies" is inappropriate definition, $47.8 \%$ of respondents agree with it.

$>51.9 \%$ of the sample disagrees with the final inappropriate sentence that describes corporate governance as a something that "is not important or necessary in the company".

Table 4.1.1 Appropriate \& Inappropriate Statements

\begin{tabular}{|c|c|c|c|c|}
\hline & & Agree & Neutral & Disagree \\
\hline \multirow[t]{3}{*}{$\begin{array}{l}\text { Appropriate } \\
\text { Statements }\end{array}$} & $\begin{array}{l}\text { Means a set of regulations and structures which } \\
\text { govern the relationship between shareholders and } \\
\text { management }\end{array}$ & $186(68.9 \%)$ & $60(22.2 \%)$ & $24(8.9 \%)$ \\
\hline & $\begin{array}{l}\text { Means the system by which companies are } \\
\text { controlled and managed }\end{array}$ & $170(63.0 \%)$ & $66(24.4 \%)$ & $32(11.9 \%)$ \\
\hline & $\begin{array}{l}\text { Clarifies and codifies the powers of managers and } \\
\text { owners in the company }\end{array}$ & $178(65.9 \%)$ & $63(23.3 \%)$ & $28(10.4 \%)$ \\
\hline \multirow[t]{3}{*}{$\begin{array}{l}\text { Inappropriate } \\
\text { Statements }\end{array}$} & $\begin{array}{l}\text { Means the government owns through its funds at } \\
\text { least } 5 \% \text { of the shares of listed companies }\end{array}$ & $111(41.1 \%)$ & $72(26.7 \%)$ & $86(31.9 \%)$ \\
\hline & $\begin{array}{l}\text { Means appointment of members by the government } \\
\text { to represent it in the management of insolvent } \\
\text { companies }\end{array}$ & $129(47.8 \%)$ & $58(21.5 \%)$ & $81(30.0 \%)$ \\
\hline & Is not important or necessary in the company & $44(16.3 \%)$ & $80(29.6 \%)$ & $140(51.9 \%)$ \\
\hline
\end{tabular}




\subsection{Dependence of Corporate Governance Information on Investment Decision}

To measure the investors' dependence of corporate governance mechanisms, following 6 most important factors were addressed:

1. Changes in the ownership of major shareholders

2. The company's commitment to appoint between three and eleven members to the board of directors

3. The presence of independent and non-executive members on the board of directors in addition to the executive members

4. Full disclosure of compensations of the board of directors members compensation

5. Disclosure of the company's essential information concerning the developments and major events

6. Transparency of the company

Table 4.2.1 presents the frequencies and percentages of investors' respondents to the factors that related to the corporate governance effected their investment decisions. The results can be concluded as follows:

> $30.7 \%$ of Saudi investors sometimes make their investment decisions depending on "changes in the ownership of major shareholders".

$>$ Only $5.2 \%$ of respondents always depend on the information that shows "the company's commitment to appoint between three and eleven members to the board of directors", and $32.2 \%$ of them never use this information when they invest in a specific company.

$27 \%$ of investors are never putting "the presence of independent and non-executive members on the board of directors in addition to the executive members" as a base for their investment decision.

$>$ "Full disclosure of compensations of the board of directors' members' compensation" never affect $22.6 \%$ of Saudi investors' decisions.

$40 \%$ of respondents always build their investment decision depending on disclosure of the company's essential information concerning the developments and major events.

D Transparency of the company always effect $41.1 \%$ of respondents' decisions, and often effect $31.9 \%$ of them.

Table 4.2.1 Frequencies and percentages of investors' respondents to the factors that related to the corporate governance effected their investment decisions

\begin{tabular}{|c|c|c|c|c|c|}
\hline Statements & Always & Often & Sometimes & Rarely & Never \\
\hline Changes in the ownership of major shareholders & $34(12.6 \%)$ & $\begin{array}{r}58 \\
(21.5 \%)\end{array}$ & $\begin{array}{r}83 \\
(30.7 \%)\end{array}$ & $\begin{array}{r}58 \\
(21.5 \%)\end{array}$ & $\begin{array}{r}36 \\
(13.3 \%)\end{array}$ \\
\hline $\begin{array}{l}\text { The company's commitment to appoint between } \\
\text { three and eleven members to the board of directors }\end{array}$ & $\begin{array}{r}14 \\
(5.2 \%)\end{array}$ & $\begin{array}{r}37 \\
(13.7 \%)\end{array}$ & $\begin{array}{r}54 \\
(20.0 \%)\end{array}$ & $\begin{array}{r}75 \\
(27.8 \%)\end{array}$ & $\begin{array}{r}87 \\
(32.2 \%)\end{array}$ \\
\hline $\begin{array}{l}\text { The presence of independent and non-executive } \\
\text { members on the board of directors in addition to the } \\
\text { executive members }\end{array}$ & $\begin{array}{r}23 \\
(8.5 \%)\end{array}$ & $\begin{array}{r}55 \\
(20.4 \%)\end{array}$ & $\begin{array}{r}61 \\
(22.6 \%)\end{array}$ & $\begin{array}{r}58 \\
(21.5 \%)\end{array}$ & $\begin{array}{r}73 \\
(27.0 \%)\end{array}$ \\
\hline $\begin{array}{l}\text { Full disclosure of compensations of the board of } \\
\text { directors members compensation }\end{array}$ & $\begin{array}{r}46 \\
(17.0 \%)\end{array}$ & $\begin{array}{r}56 \\
(20.7 \%)\end{array}$ & $\begin{array}{r}59 \\
(21.9 \%)\end{array}$ & $\begin{array}{r}46 \\
(17.0 \%)\end{array}$ & $\begin{array}{r}61 \\
(22.6 \%)\end{array}$ \\
\hline $\begin{array}{l}\text { Disclosure of the company's essential information } \\
\text { concerning the developments and major events }\end{array}$ & $\begin{array}{r}108 \\
(40.0 \%)\end{array}$ & $\begin{array}{r}88 \\
(32.6 \%)\end{array}$ & $\begin{array}{r}54 \\
(20.0 \%)\end{array}$ & $\begin{array}{r}12 \\
(4.4 \%)\end{array}$ & $\begin{array}{r}8 \\
(3.0 \%)\end{array}$ \\
\hline Transparency of the company & $\begin{array}{r}111 \\
(41.1 \%)\end{array}$ & $\begin{array}{r}86 \\
(31.9 \%)\end{array}$ & $\begin{array}{r}46 \\
(17.0 \%)\end{array}$ & $\begin{array}{r}17 \\
(6.3 \%)\end{array}$ & $\begin{array}{r}4 \\
(3.3 \%)\end{array}$ \\
\hline
\end{tabular}

\subsection{The Importance of Corporate Governance Mechanisms for Investors}

To measure the importance of corporate governance mechanisms for investors, 8 statements that related to the most important corporate governance mechanisms where addressed.

The statements are:

1. Number of members of the board of directors

2. Existence of independent and non-executive members (in addition to the executive members) in the Board of directors

3. The ownership of government/sovereign funds in the company

4. Disclosure of board members' compensations

5. The existence of nomination and compensation committee in the company 
6. Transparency of the company in general

Table 4.3.1 presents the frequencies and percentages of investor's respondents to the importance of corporate governance mechanisms for them. The results can be concluded as follows:

$>26.3 \%$ of the total of 270 investors believes that "the number of board of directors" is not important corporate governance element.

$>$ With regard to the statement "Existence of independent and non-executive members (in addition to the executive members) in the Board of directors", it is found that $50 \%$ of the respondents believe of its importance as corporate governance mechanism.

$>66.6 \%$ of Saudi investors said that "the ownership of government/sovereign funds in the company" is important information about any company.

$>$ "Disclosure of board members' compensations" is very important as $32.6 \%$ of respondents answered.

$>$ "Disclosure of penalties and sanctions imposed on the company by the Capital Market Authority" is very important factor for $47.8 \%$ of the sample

$>$ "The existence of nomination and compensation committee in the company" is very important information for $35.2 \%$ of Saudi investors and only $4.1 \%$ see is as unimportant at all.

$>\quad 63.3 \%$ of the sample believes that "Transparency of the company in general" is a very important corporate governance mechanism.

Table 4.3.1 Frequencies and percentage of investors' respondents to the importance of corporate governance mechanisms

\begin{tabular}{|c|c|c|c|c|c|}
\hline Statements & Very imp. & Important & Neutral & unimportant & $\begin{array}{l}\text { Unimportant } \\
\text { all }\end{array}$ \\
\hline $\begin{array}{l}\text { Number of members of the board of } \\
\text { directors }\end{array}$ & $\begin{array}{r}62 \\
(23.0 \%)\end{array}$ & $\begin{array}{r}60 \\
(22.2 \%)\end{array}$ & $\begin{array}{r}61 \\
(22.6 \%)\end{array}$ & $\begin{array}{r}71 \\
(26.3 \%)\end{array}$ & $\begin{array}{r}14 \\
(5.2 \%)\end{array}$ \\
\hline $\begin{array}{l}\text { Existence of independent and non-executive } \\
\text { members (in addition to the executive } \\
\text { members) in the Board of directors }\end{array}$ & $\begin{array}{r}54 \\
(20.0 \%)\end{array}$ & $\begin{array}{r}81 \\
(30.0 \%)\end{array}$ & $\begin{array}{r}78 \\
(28.9 \%)\end{array}$ & $\begin{array}{r}40 \\
(14.8 \%)\end{array}$ & $\begin{array}{r}13 \\
(4.8 \%)\end{array}$ \\
\hline $\begin{array}{l}\text { The ownership of government/sovereign } \\
\text { funds in the company }\end{array}$ & $\begin{array}{r}77 \\
(28.5 \%)\end{array}$ & $\begin{array}{r}103 \\
(38.1 \%)\end{array}$ & $\begin{array}{r}56 \\
(20.7 \%)\end{array}$ & $\begin{array}{r}21 \\
(7.8 \%)\end{array}$ & $\begin{array}{r}10 \\
(3.7 \%)\end{array}$ \\
\hline $\begin{array}{l}\text { Disclosure of board members' } \\
\text { compensations }\end{array}$ & $\begin{array}{r}88 \\
(32.6 \%)\end{array}$ & $\begin{array}{r}74 \\
(27.4 \%)\end{array}$ & $\begin{array}{r}54 \\
(20.0 \%)\end{array}$ & $\begin{array}{r}36 \\
(13.3 \%)\end{array}$ & $\begin{array}{r}15 \\
(5.6 \%)\end{array}$ \\
\hline $\begin{array}{l}\text { The existence of nomination and } \\
\text { compensation committee in the company }\end{array}$ & $\begin{array}{r}95 \\
(35.2 \%)\end{array}$ & $\begin{array}{r}93 \\
(34.4 \%)\end{array}$ & $\begin{array}{r}50 \\
(18.5 \%)\end{array}$ & $\begin{array}{r}20 \\
(7.4 \%)\end{array}$ & $\begin{array}{r}11 \\
(4.1 \%)\end{array}$ \\
\hline Transparency of the company in general & $\begin{array}{r}171 \\
(63.3 \%) \\
\end{array}$ & $\begin{array}{r}62 \\
(23.0 \%) \\
\end{array}$ & $\begin{array}{r}29 \\
(8.9 \%) \\
\end{array}$ & $\begin{array}{r}9 \\
(3.3 \%) \\
\end{array}$ & $\begin{array}{r}3 \\
(1.1 \%) \\
\end{array}$ \\
\hline
\end{tabular}

\section{Analytical Result Analysis}

\subsection{Testing Investors'Awareness of Corporate Governance Concepts According to Their Characteristics}

In this part, the hypothesis testing (Chi-Square test) will be conducted to examine whether the investors are alike in their awareness of the corporate governance concepts, no matter of the differences in their genders.

5.1.1 The Statement "Corporate Governance Means that the Government Owns at Least $5 \%$ of the Shares of Listed Companies, Through Its Funds."

Table 5.1.1.1 presents outputs of the hypothesis test of investors' agreement toward the statement "Corporate governance means that the government owns through its funds at least $5 \%$ of the shares of listed companies" according to the gender. The main findings are stated as follows:

$>$ There is an agreement between male and female investors regarding the statement "Corporate governance means that the government owns through its funds at least $5 \%$ of the shares of listed companies" as the concept of corporate governance. That means, $41.4 \%$ of investors think that this statement is a concept of corporate governance no matter of their gender. 
Table 5.1.1.1 Frequencies/percentages of investors responding to the statement "Corporate governance means the government owns through its funds at least $5 \%$ of the shares of listed companies" as a definition of corporate governance

\begin{tabular}{|c|c|c|c|c|}
\hline Gender & Agree & Neutral & Disagree & Total \\
\hline Male & $89(42.0 \%)$ & $52(24.5)$ & $71(33.5 \%)$ & 212 \\
\hline Female & $22(39.3)$ & 19 (33.9) & $15(26.8)$ & 56 \\
\hline Total & $111(41.4 \%)$ & $71(26.5 \%)$ & $86(32.1 \%)$ & 268 \\
\hline $\begin{array}{l}\text { Is there } \\
\text { "Corpore }\end{array}$ & $\begin{array}{l}\text { female invest } \\
\text { overnment ow }\end{array}$ & $\begin{array}{l}\text { e statement } \\
\text { ands at least }\end{array}$ & P-Value & 0.337 \\
\hline $\begin{array}{l}5 \% \text { of th } \\
0.05 \% 1\end{array}$ & s a definition & vernance, at & Decision & Yes \\
\hline
\end{tabular}

5.1.2 The Statement "Corporate Governance Means a Set of Regulations and Structures which Govern the Relationship Between Shareholders and Management"

Table 5.1.2.1 presents outputs of the hypothesis test of investors' agreement toward "Corporate governance means a set of regulations and structures which govern the relationship between shareholders and management" statement according to gender. The main findings are stated as follows:

$>\quad$ There is an agreement between male and female investors regarding the statement "Corporate governance means a set of regulations and structures which govern the relationship between shareholders and management." That means, $69.1 \%$ of investors think that the statement is a definition of corporate governance no matter of their gender.

Table 5.1.2.1 Frequencies/percentages of investors respondents to the statement "Corporate governance means a set of regulations and structures which govern the relationship between shareholders and management" as a definition of corporate governance

\begin{tabular}{|c|c|c|c|c|}
\hline Gender & Agree & Neutral & Disagree & Total \\
\hline Male & $147(69.0 \%)$ & $48(22.5 \%)$ & $18(8.5 \%)$ & 213 \\
\hline Female & $39(69.6 \%)$ & $11(19.6 \%)$ & $6(10.7 \%)$ & 56 \\
\hline Total & $186(69.1 \%)$ & $59(21.9 \%)$ & $24(8.9 \%)$ & 269 \\
\hline \multicolumn{3}{|c|}{$\begin{array}{l}\text { Is there an agreement between male \& female investors regarding the statement "Corporate } \\
\text { governance means a set of regulations and structures which govern the relationship between } \\
\text { shareholders and management" as a definition of corporate governance, at } 0.05 \% \text { level? }\end{array}$} & P-Value & 0.808 \\
\hline
\end{tabular}

5.1.3 The Statement "Corporate Governance Means Appointment of Members by the Government to Represent It in the Management of Insolvent Companies"

Table 5.1.3.1 presents outputs of the hypothesis test of the agreement of investors toward the statement "Corporate governance means the appointment of members by the government to represent it in the management of insolvent companies" according to gender. The main findings are stated as follows:

$>\quad$ There is an agreement between male and female investors regarding the statement "Corporate governance means the appointment of members by the government to represent it in the management of insolvent companies" as a definition of corporate governance. That means, $48.3 \%$ of investors think that this statement is a definition of corporate governance no matter of their gender.

Table 5.1.3.1 Frequencies/percentages of investors responding to the statement "Corporate governance means the appointment of members by the government to represent it in the management of insolvent companies" as a definition of corporate governance

\begin{tabular}{|c|c|c|c|c|}
\hline Gender & Agree & Neutral & Disagree & Total \\
\hline Male & $98(46.4 \%)$ & $43(20.4 \%)$ & $70(33.2 \%)$ & 211 \\
\hline Female & $31(55.4 \%)$ & $14(25.0 \%)$ & $11(19.6 \%)$ & 56 \\
\hline Total & $129(48.3 \%)$ & $57(21.3 \%)$ & $81(30.3 \%)$ & 267 \\
\hline $\begin{array}{l}\text { Is there a } \\
\text { "Corporat }\end{array}$ & male \& female & $\begin{array}{l}\text { e statement } \\
\text { zernment to }\end{array}$ & P-Value & 0.146 \\
\hline
\end{tabular}
governance, at $0.05 \%$ level?

5.1.4 The Statement "Corporate Governance Means the System by which Companies are Controlled and Managed"

Table 5.1.4.1 presents outputs of the hypothesis test of the agreement of investors toward the statement "Corporate governance means the system by which companies are controlled and managed" as a definition of corporate governance according to gender. The main findings are stated as follows: 
There is an agreement between male and female investors regarding the statement "Corporate governance means the system by which companies are controlled and managed" as a definition of corporate governance. That means, $63.7 \%$ of investors think that this statement is a definition of corporate governance no matter of their gender.

Table 5.1.4.1 Frequencies/percentages of investors responding to the statement "Corporate governance means the system by which companies are controlled and managed" as a definition of corporate governance

\begin{tabular}{|c|c|c|c|c|}
\hline Gender & Agree & Neutral & Disagree & Total \\
\hline Male & $136(64.5 \%)$ & $52(24.6 \%)$ & $23(10.9 \%)$ & 211 \\
\hline Female & $34(60.7 \%)$ & $13(23.2 \%)$ & $9(16.1 \%)$ & 56 \\
\hline Total & $170(63.7 \%)$ & $65(24.3 \%)$ & $32(12.0 \%)$ & 267 \\
\hline $\begin{array}{l}\text { Is there } \\
\text { "Corporat } \\
\text { managed' }\end{array}$ & $\begin{array}{l}\text { ale \& female } \\
\text { system by w } \\
\text { te governance }\end{array}$ & $\begin{array}{l}\text { statement } \\
\text { trolled and }\end{array}$ & P-Value & 0.571 \\
\hline
\end{tabular}

5.1.5 The Statement "Corporate Governance Clarifies and Codifies the Powers of Managers and Owners in the Company"

Table 5.1.5.1 presents outputs of the hypothesis test of the agreement of investors toward the statement "Clarifies and codifies the powers of managers and owners in the company" as a definition of corporate governance according to the gender. The main findings are stated as follows:

$>\quad$ There is an agreement between male and female investors regarding the statement "Corporate governance clarifies and codifies the powers of managers and owners in the company" as a definition of corporate governance. That means, $66.4 \%$ of investors think that this statement is a definition of corporate governance no matter of their gender.

Table 5.1.5.1 Frequencies/percentages of investors responding to the statement "Corporate governance clarifies and codifies the powers of managers and owners in the company" as a definition of corporate governance

\begin{tabular}{|c|c|c|c|c|}
\hline Gender & Agree & Neutral & Disagree & Total \\
\hline Male & $143(67.5 \%)$ & $47(22.2 \%)$ & $22(10.4 \%)$ & 212 \\
\hline Female & $35(62.5 \%)$ & $15(26.8 \%)$ & $6(10.7 \%)$ & 56 \\
\hline Total & $178(66.4 \%)$ & $62(23.1 \%)$ & $28(10.4 \%)$ & 268 \\
\hline & & & P-Value & 0.750 \\
\hline
\end{tabular}

5.1.6 The Statement "Corporate Governance Is not Important or Necessary in the Company"

Table 5.1.6.1 presents outputs of the hypothesis test of the agreement of investors toward the statement "Corporate governance is not important or necessary in the company" according to gender. The main findings are stated as follows:

$>\quad$ There is an agreement between male and female investors regarding the statement "Corporate governance is not important or necessary in the company." That means, 53.2\% of investors disagree with this statement no matter of their gender.

Table 5.1.6.1 Frequencies/percentages of investors responding to the statement "Corporate governance is not important or necessary in the company"

\begin{tabular}{|c|c|c|c|c|}
\hline Gender & Agree & Neutral & Disagree & Total \\
\hline Male & $33(15.6 \%)$ & $67(31.8 \%)$ & $111(52.6 \%)$ & 211 \\
\hline Female & $11(21.2 \%)$ & $12(23.1 \%)$ & $29(55.8 \%)$ & 52 \\
\hline Total & $44(16.7 \%)$ & $79(30.0 \%)$ & $140(53.2 \%)$ & 263 \\
\hline $\begin{array}{l}\text { Is there } \\
\text { governan }\end{array}$ & $\begin{array}{l}\text { e \& female } \\
\text { sary in the co }\end{array}$ & "Corporate & $\begin{array}{l}\text { P-Value } \\
\text { Decision }\end{array}$ & $\begin{array}{r}0.390 \\
\text { Yes }\end{array}$ \\
\hline
\end{tabular}

\subsection{Testing the Importance of Corporate Governance Mechanism for Saudi Investors According to Their} Characteristics

In this part, the hypothesis testing (Chi-Square test) is conducted to examine whether or not the investors care about corporate governance mechanisms no matter of the differences of their characteristics pertained to the gender.

\subsubsection{The Statement "Number of Members of the Board of Directors"}

Table 2.2.1.1 presents outputs of the hypothesis test of investors' agreement toward the statement "Number of members of the board of directors" as an important mechanism of corporate governance according to gender. The main findings are stated as follows: 
$>\quad$ There is an agreement between male and female investors regarding the statement "Number of members of the board of directors" as an important mechanism of corporate governance. That means, $26.6 \%$ of investors agree that this statement is not an important factor of corporate governance no matter of their gender.

Table 5.2.1.1 Frequencies/percentages of investors responding to the statement "Number of members of the board of directors" as an important mechanism of corporate governance

\begin{tabular}{|c|c|c|c|c|c|c|}
\hline Gender & $\begin{array}{r}\text { Vary } \\
\text { Important }\end{array}$ & Important & Neutral & Unimportant & Unimportant at all & Total \\
\hline Male & $51(24.1 \%)$ & $50(23.6 \%)$ & $46(21.7 \%)$ & $53(25.0 \%)$ & $12(5.7 \%)$ & 212 \\
\hline Female & $11(20.0 \%)$ & $9(16.4 \%)$ & $15(27.3 \%)$ & $18(32.7 \%)$ & $2(3.6 \%)$ & 55 \\
\hline Total & $62(23.2 \%)$ & $59(22.1 \%)$ & $61(22.8 \%)$ & $71(26.6 \%)$ & $14(5.2 \%)$ & 267 \\
\hline $\begin{array}{l}\text { Is there } \\
\text { membe }\end{array}$ & between ma & male in & $\operatorname{ardin}$ & of & $\begin{array}{l}\text { P-Value } \\
\text { Decision }\end{array}$ & $\begin{array}{r}0.516 \\
\text { Yes }\end{array}$ \\
\hline
\end{tabular}
$0.05 \%$ level?

5.2.2 The Statement "Existence of Independent and Non-executive Members (in Addition to the Executive Members) in the Board of Directors"

Table 5.2.2.1 presents outputs of the hypothesis test of investors' agreement toward the statement "Existence of independent and non-executive members (in addition to the executive members) in the board of directors" as an important mechanism of corporate governance according to gender. The main findings are stated as follows:

$>$ There is an agreement between male and female investors regarding the statement "Existence of independent and non-executive members (in addition to the executive members) in the board of directors" as an important mechanism of corporate governance. That means, $30.2 \%$ of investors agree that this statement is an important factor of the corporate governance no matter of their gender.

Table 5.2.2.1 Frequencies/percentages of investors responding to the statement "Existence of independent and non-executive members (in addition to the executive members) in the board of directors" as an important mechanism of corporate governance?

\begin{tabular}{|c|c|c|c|c|c|c|}
\hline Gender & $\begin{array}{r}\text { Vary } \\
\text { Important }\end{array}$ & Important & Neutral & Unimportant & Unimportant at all & Total \\
\hline Male & $46(21.9 \%)$ & $67(31.9 \%)$ & $58(27.6 \%)$ & $29(13.8 \%)$ & $10(4.8 \%)$ & 210 \\
\hline Female & $8(14.5 \%)$ & $13(23.6 \%)$ & $20(36.4 \%)$ & $11(20.0 \%)$ & $3(5.5 \%)$ & 55 \\
\hline Total & $54(20.4 \%)$ & $80(30.2 \%)$ & $78(29.4 \%)$ & $40(15.1 \%)$ & $13(4.9 \%)$ & 265 \\
\hline $\begin{array}{l}\text { Is there } \\
\text { indepe }\end{array}$ & & male i & & & $\begin{array}{l}\text { P-Value } \\
\text { Decision }\end{array}$ & $\begin{array}{r}0.351 \\
\text { Yes }\end{array}$ \\
\hline
\end{tabular}

of directors" as an important mechanism of corporate governance, at $0.05 \%$ level?

5.2.3 The Statement "The Ownership of Government/Sovereign Funds in the Company":

Table 5.2.3.1 presents outputs of the hypothesis test of investors' agreement toward the statement "The ownership of government/sovereign funds in the company" as an important mechanism of corporate governance according to gender. The main findings are stated as follows:

$>\quad$ There is no agreement between male and female investors regarding the statement "The ownership of government/sovereign funds in the company" as an important mechanism of corporate governance. From 210 males, $40.0 \%$ of them agree that the statement is important and $33.3 \%$ of them strongly agree with that. However, $35.7 \%$ of females are neutral about this statement and $32.1 \%$ of them agree that it is importance.

Table 5.2.3.1 Frequencies/percentages of investors responding to the statement "The ownership of government/sovereign funds in the company" as an important mechanism of corporate governance

\begin{tabular}{|c|c|c|c|c|c|c|}
\hline Gender & $\begin{array}{r}\text { Vary } \\
\text { Important }\end{array}$ & Important & Neutral & Unimportant & $\begin{array}{r}\text { Unimportant at } \\
\text { all }\end{array}$ & Total \\
\hline Male & $70(33.3 \%)$ & $84(40.0 \%)$ & $36(17.1 \%)$ & $12(5.7 \%)$ & $8(3.8 \%)$ & 210 \\
\hline Female & $7(12.5 \%)$ & $18(32.1 \%)$ & $20(35.7 \%)$ & $9(16.1 \%)$ & $2(3.6 \%)$ & 56 \\
\hline Total & $77(28.9 \%)$ & $102(38.3 \%)$ & $56(21.1 \%)$ & $21(7.9 \%)$ & $10(3.8 \%)$ & 266 \\
\hline $\begin{array}{l}\text { Is there } \\
\text { ownersh }\end{array}$ & between & female inve & regardi & $\begin{array}{l}\text { ent "The } \\
\text { echanism }\end{array}$ & $\begin{array}{l}\text { P-Value } \\
\text { Decision }\end{array}$ & $\begin{array}{r}0.000 \\
\text { No }\end{array}$ \\
\hline
\end{tabular}

\subsubsection{The Statement "Disclosure of Board Members' Compensations"}

Table 5.2.4.1 presents outputs of the hypothesis test of investors' agreement toward the statement "Disclosure of board members' compensations" as an important mechanism of corporate governance according to gender. The main findings are stated as follows: 
$>\quad$ There is an agreement between male and female investors regarding the statement "Disclosure of board members' compensations" as an important mechanism of corporate governance. That means, $33.1 \%$ of investors strongly agree that this statement is an important factor of corporate governance no matter of their gender.

Table 5.2.4.1 Frequencies/percentages of investors responding to the statement "Disclosure of board members' compensations" as an important mechanism of corporate governance

\begin{tabular}{|c|c|c|c|c|c|c|}
\hline Gender & $\begin{array}{r}\text { Vary } \\
\text { Important }\end{array}$ & Important & Neutral & Unimportant & Unimportant at all & Total \\
\hline Male & $75(35.4 \%)$ & $56(26.4 \%)$ & $41(19.3 \%)$ & $27(12.7 \%)$ & $13(6.1 \%)$ & 212 \\
\hline Female & $13(24.1 \%)$ & $17(31.5 \%)$ & $13(24.1 \%)$ & $9(16.7 \%)$ & $2(3.7 \%)$ & 54 \\
\hline Total & $88(33.1 \%)$ & $73(27.4 \%)$ & $54(20.3 \%)$ & $36(13.5 \%)$ & $15(5.6 \%)$ & 266 \\
\hline $\begin{array}{l}\text { Is there } \\
\text { "Disclos }\end{array}$ & $\begin{array}{l}\text { it between } \\
\text { hembers' co }\end{array}$ & $\begin{array}{l}\& \text { female } \\
\text { ations" as }\end{array}$ & $\begin{array}{l}\text { ors reg } \\
\text { rtant } m\end{array}$ & $\begin{array}{l}\text { statement } \\
\text { corporate }\end{array}$ & $\begin{array}{l}\text { P-Value } \\
\text { Decision }\end{array}$ & $\begin{array}{r}0.372 \\
\text { Yes }\end{array}$ \\
\hline
\end{tabular}
governance?

5.2.5 The Statement "The Existence of Nomination and Compensation Committee in the Company"

Table 5.2.5.1 presents outputs of the hypothesis test of investors' agreement toward the statement "The existence of nomination and compensation committee in the company" as an important mechanism of corporate governance according to gender. The main findings are stated as follows:

$>$ There is no agreement between male and female investors regarding the statement "The existence of nomination and compensation committee in the company" as an important mechanism of corporate governance. Most of males (37.3\%) strongly agree that that factor is important while most of females (32.1\%) are neutral about it.

Table 5.2.5.1 Frequencies/percentages of investors responding to the statement "The existence of nomination and compensation committee in the company" as an important mechanism of corporate governance?

\begin{tabular}{lccrrrr}
\hline Gender & $\begin{array}{c}\text { Vary } \\
\text { Important }\end{array}$ & Important & Neutral & Unimportant & $\begin{array}{r}\text { Unimportant at } \\
\text { all }\end{array}$ & $\begin{array}{r}\text { Total } \\
\text { Male }\end{array}$ \\
Female & $19(37.3 \%)$ & $75(35.4 \%)$ & $32(15.1 \%)$ & $15(7.1 \%)$ & $11(5.2 \%)$ & 212 \\
Total & $95(35.4 \%)$ & $92(34.3 \%)$ & $50(18.7 \%)$ & $20(7.5 \%)$ & $11(4.1 \%)$ & 56 \\
\hline $\begin{array}{l}\text { Is there an agreement between male \& female investors regarding the statement "The } \\
\text { existence of nomination and compensation committee in the company" as an important }\end{array}$ & P-Value & Decision \\
mechanism of corporate governance, at $0.05 \%$ level?
\end{tabular}

\subsubsection{The Statement "Transparency of the Company in General":}

Table 5.2.6.1 presents outputs of the hypothesis test of investors' agreement toward the statement "Transparency of the company in general" as an important mechanism of corporate governance according to gender. The main findings are stated as follows:

$>\quad$ There is no agreement between male and female investors regarding the statement "Transparency of the company in general" as important mechanism of corporate governance. $67.5 \%$ of males think that the mechanism is very important and $23.6 \%$ of them think it is important. Most of females (50\%) think that the statement is very important while $23.2 \%$ of them are neutral about this mechanism.

Table 5.2.6.1 Frequencies/percentages of investors responding to the statement "Transparency of the company in general" as an important mechanism of corporate governance

\begin{tabular}{|c|c|c|c|c|c|c|}
\hline Gender & $\begin{array}{r}\text { Vary } \\
\text { Important } \\
\end{array}$ & Important & Neutral & Unimportant & $\begin{array}{r}\text { Unimportant at } \\
\text { all } \\
\end{array}$ & Total \\
\hline Male & $143(67.5 \%)$ & $50(23.6 \%)$ & $11(5.2 \%)$ & $6(2.8 \%)$ & $2(.9 \%)$ & 212 \\
\hline Female & $28(50.0 \%)$ & $11(19.6 \%)$ & $13(23.2 \%)$ & $3(5.4 \%)$ & $1(1.8 \%)$ & 56 \\
\hline Total & $171(63.8 \%)$ & $61(22.8 \%)$ & $24(9.0 \%)$ & $9(3.4 \%)$ & $3(1.1 \%)$ & 268 \\
\hline $\begin{array}{l}\text { Is there } \\
\text { of the }\end{array}$ & $\begin{array}{l}\text { between ma } \\
\text { neral" as al }\end{array}$ & $\begin{array}{l}\text { male invest } \\
\text { tant mecha }\end{array}$ & $\begin{array}{l}\text { rding the } \\
\text { corporat }\end{array}$ & $\begin{array}{l}\text { parency } \\
0.05 \%\end{array}$ & $\begin{array}{l}\text { P-Value } \\
\text { Decision }\end{array}$ & $\begin{array}{r}0.001 \\
\text { No }\end{array}$ \\
\hline
\end{tabular}

\section{Discussion}

Appropriate and inappropriate definitions have been made to examine the investors understanding of corporate governance concepts. Most of male and female investors agree with appropriate definitions. They agree with two over three of inappropriate definitions, and they think that the inappropriate definitions are appropriate 
definitions of corporate governance. Saudi investors do not know exactly the definitions of corporate governance, and they are confused about some words such as government. However, they believe that the corporate governance is important and necessary thing in companies.

Most of investors always do not depend on information or factor that related to corporate governance as a base for their investment decisions. They just depend on disclosure and transparency of companies. Male investors depend more than female investors on corporate governance to make their investment decisions because of males' work nature. I think women like to speculate more than men. In Saudi culture, men are responsible about their family as Qur'an explains in many statements. So they are careful when they make their decisions that related to money.

The investors do not care about board of directors' number, they care about board compositions. Maybe they think that the existence of independent and non-executive members will increase the control on the company which the investors are part of it. Males think that ownership structure, disclosure, and transparency are important in general.

\section{Conclusion}

Saudi investors need to be more educated about corporate governance concepts and mechanisms. They should take into account the information related to corporate governance when investing in any company. To achieve that, investors should read about how the company adhere to the corporate governance principles before investing in the company Furthermore, media must play their essential role to educate Saudi people about the meaning and importance of corporate governance. In addition, the Capital Market Authority (CMA) can consider the paper results and make the necessary changes, increase investors' awareness of corporate governance by making periodical lectures, and distributing related publications. Though Saudi investors' are aware about corporate governance concepts, and lot of them care about corporate governance mechanisms, but investors do not build their investment decision upon corporate governance information and factors.

\section{Acknowledgement}

This paper is supported by the Research Center at the College of Business Administration and the Deanship of Scientific Research at King Saud University, Riyadh.

\section{References}

Ahmed, A., \& Ali, S. (2017). Boardroom gender diversity and stock liquidity: Evidence from Australia. Journal of Contemporary Accounting \& Economics, 13(2), 148-165. https://doi.org/10.1016/j.jcae.2017.06.001

Ahmed, A., Monem, R. M., Delaney, D., \& Ng, C. (2017). Gender diversity in corporate boards and continuous disclosure: Evidence from Australia. Journal of Contemporary Accounting \& Economics, 13(2), 89-107. https://doi.org/10.1016/j.jcae.2017.05.004

Beasley, M. S., Carcello, J. V., Hermanson, D. R., \& Lapides, P. (2000). Fraudulent financial reporting: consideration of industry traits and corporate governance mechanisms. Account Horizons, 14(4), 441-454. https://doi.org/10.2308/acch.2000.14.4.441

Bhagat, B., \& Black, B. (1999). The certain relationship between board composition and firm performance, Business Lawer, 54, 921-963.

Bhagat, B., \& Black, B. (2002). The Non-Correlation between Board Independence And Long-Term Firm Performance. Journal of Corporation Law, 27, 231-273.

Bhuiyan, H. U., \& Biswas, P. K. (2006), Agency Problem and the Role of Corporate Governance. The Bangladesh Accountant, 52(25), 109-117.

Bilimoria, D., \& Piderit, S. K. (1994). Board Committee Membership: Effects of Sex-Based Bias. Academy of Management Journal, 37(6), 1453-1477. https://doi.org/10.2307/256795

Blair, M. M. (1995), Ownership and control: rethinking corporate governance for the twenty-first century, Brookings Institution, Washington DC, 1-372.

Branson, M. B. (2007). Still Square Pegs in Round Holes - A Look at ANCSA Corporations, Corporate Governance, and Indeterminate Form or Operation of Legal Entities. Alaska L. Rev., 24, 203-212.

Cadbury, A. (1992). Codes of Best Practice. Report from the committee on Financial Aspects of Corporate Governance. London, Gee Publishing.

CAPITAL MARKET AUTHORITY CORPORATE GOVERNANCE REGULATIONS IN THE KINGDOM OF 
SAUDI ARABIA, Issued by the Board of Capital Market Authority Pursuant to Resolution No. 1/212/2006 dated 21/10/1427AH (corresponding to 12/11/2006), 1-19.

Carter, D. A., Simkins, B. J., \& Simpson, W. G. (2003). Corporate governance, board diversity and firm value. The Financial Review, 38, 33-53. https://doi.org/10.1111/1540-6288.00034

Che Haat, M. H., Abdul, R. R., \& Mahenthiran, S. (2008). Corporate governance, transparency and performance of Malaysian companies. Managerial Auditing Journal, 23(8), 744-778. https://doi.org/10.1108/02686900810899518

Conyon, M. J., \& He, L. (2017). Firm performance and boardroom gender diversity: A quantile regression approach. Journal of Business Research, 79, 198-211. https://doi.org/10.1016/j.jbusres.2017.02.006

Daily, C., \& Dalton, D. (1993). Board of Directors Leadership and Structure: Control and Performance Implications. Journal of Financial Economics, 1, 55-64. https://doi.org/10.1177/104225879301700305

Davidson, W. N., Pilger, T., \& Szakmary, A. (2004). The importance of board composition and committee structure: The case of poison pills. Corporate Ownership \& Control, 1(3), 81-95. https://doi.org/10.22495/cocv1i3p8

Davis, G. F., \& Useem, M. (2001). Top Management, Company Directors and Corporate Control, 11th Chapter, Handbbok of Strategy \& Management, edited by Andrew M Pettigrew, Howard Thomas, Richard Whittington, Sage Publication, 232-260.

Du Plessis, J., McConvill, J., \& Bagaric, M. (2005). Principles of contemporary corporate governance (2nd edn), Cambridge University Press, UK; ISBN 0-521-61783-9; PB; 416 pages. https://doi.org/10.1017/CBO9780511813481

Durnev, A., \& Kim, E. H. (2003). To steal or not to steal: firm attributes, legal environment and valuation. University of Michigan, Working paper series, No. 554, 2003. https://doi.org/10.2139/ssrn.391132

Fama, E. F., \& Jensen, M. C. (1983). Separation of Ownership and Control. Journal of Law and Economics, 26, 301-325. https://doi.org/10.1086/467037

Fombrun, C. J. (2006). Corporate Governance. Corporate Reputation Review, 8(4), 267-271. https://doi.org/10.1057/palgrave.crr.1540254

Heidrick and Struggles. (2009). Corporate Governance Report 2009: Boards in turbulent times, Paris. https://stats.gov.sa (General Authority for Statistics)

Heidrick and Struggles/ USC Center for Effective Organizations. (2007). 10th Annual Board Effectiveness Study, 2006-2007.

Jensen, M. C. (1993). The modern industrial revolution, Exit, and the failure of internal control systems. The Journal of Finance, 48(3), 831-880. https://doi.org/10.1111/j.1540-6261.1993.tb04022.x

Johnson, S., Boone, P., Breach, A., \& Friedman, E. (2000). Corporate governance in the Asian financial crisis. Journal of Financial Economics, 1, 1-36. https://doi.org/10.1016/S0304-405X(00)00069-6

Kesner, I. F. (1988). Director's characteristics and committee membership: An investigation of type, occupation, tenure, and gender. Academy of Management Journal, 31, 66-84. https://doi.org/10.2307/256498

Kesner, I. F., Victor, B., \& Lamont, B. T. (1986). Board Composition and the Commission of Illegal Acts: An Investigation of Fortune 500 Companies. The Academy of management Journal, 29(4), 789-799. https://doi.org/10.2307/255945

Khan, A. R., Javed, S., \& Dewan, M. H. (2004). Reporting on Corporate Governance as a Voluntary Disclosure: A Study on the Annual Reports of BEXIMCO Group. Dhaka University Journal of Business Studies, 25(1), 131-145.

La Porta, R., \& Lopez, F. (1999). Corporate ownership around the world. Journal of Finance, 54(2), 471-517. https://doi.org/10.1111/0022-1082.00115

La Porta, R., \& Vishny, R. (1997). Legal determinants of external finance. Journal of Finance, 52(3), 1131-1150. https://doi.org/10.1111/j.1540-6261.1997.tb02727.x

La Porta, R., Lopez-de-Silanes, F., Shleifer, A., \& Vishny, R. (2000). Investor protection and corporate valuation. Journal of Finance, 57, 1147-1170. https://doi.org/10.1111/1540-6261.00457

La Porta, R., Silance, F., Shleifer, A., \& Vishny, R. (1998). Law and Finance. Journal of Political Economy, 106, 
1113-1150. https://doi.org/10.1086/250042

Lipton, M., \& Lorsch, J. (1992). A modest proposal for improved corporate governance. Business Lawyer, 48, 59-77.

List of Corporate collapses and scandals. From Wikipedia, the free encyclopedia https://en.wikipedia.org/wiki/List_of_corporate_collapses_and_scandals

Lorsch, J. W., \& MacIver, E. (1989). Pawns or Potentates: The Reality of America's Corporate Boards, Boston, MA, Harvard Business School Press, 1989.

Lutzy, J. M. (2003). Analysis of the proposed NYSE corporate governance and audit committee listing requirements. DePaul Business \& Commercial Journal, 2(99), 99-164.

Monks, R., \& Minow, N. (2001). Corporate Governance: Second Edition (Malden, MA: Blackwell Publishers, 2001).

Organisation for Economic Co-operation and Development (OECD). (2004). OECD Principles of Corporate Governance. Paris, France: OECD Publishing.

Pearce, J. A., \& Zahra, S. A. (1992). BOARD COMPOSITION FROM A STRATEGIC CONTINGENCY PERSPECTIVE. Journal of Management Studies, 29(4), 411-438. https://doi.org/10.1111/j.1467-6486.1992.tb00672.x

Pfeffer, J. (1972). Size and Composition of Corporate Boards of Directors: The Organization and its Environment. Administrative Science Quarterly, 17(2), 218-228. https://doi.org/10.2307/2393956

Prempeh, K. B, \& Eugane, M. O. (2015). Corporate governance structure and shareholder wealth maximization, Munich Personal RePEc Archive, Working paper series, No. 68087.

Rose, P. (2006-07), The Corporate Governance Industry, Journal of Corporate Law, 32, 887-899.

Schellendger, M. H., Wood, D. D., \& Tashakori, A. (1989), Board of Director Composition, Shareholder Wealth, and Dividend Policy. Journal Of Management, 15(3), 457-467. https://doi.org/10.1177/014920638901500308

Sila, V., Gonzalez, A., \& Hagendorff, J. (2016). Women on board: Does boardroom gender diversity affect firm risk? Journal of Corporate Finance, 36, 26-53. https://doi.org/10.1016/j.jcorpfin.2015.10.003

Thompson, S. (1992). Sampling, Wiley, pp38.

Tricker, B. (2000). Valedictory editorial: So-long, and thanks for all the fish. Corporate Governance: An International Review, 8(4), 403-405. https://doi.org/10.1111/1467-8683.00220

Wymeersch, E. (2006). Corporate Governance Codes and their implementation. University of Ghant, Financial Law Institute, working paper series no.2006-10. https://doi.org/10.1515/9783110915648.619

www.ssrn.com

www.search.epnet.com

www.google.com

www.investopedia.com

www.wikipedia.com

\section{Copyrights}

Copyright for this article is retained by the author(s), with first publication rights granted to the journal.

This is an open-access article distributed under the terms and conditions of the Creative Commons Attribution license (http://creativecommons.org/licenses/by/4.0/). 